\title{
Review of the Chemical Properties, Pharmacological Properties, and Development Studies of Cymbopogon sp.
}

\author{
Aliya Azkia Zahra ${ }^{1, *}$, Rika Hartati ${ }^{2}$ (D) , Irda Fidrianny ${ }^{3}$ (D) \\ 1 Department of Pharmaceutical Biology, School of Pharmacy, Bandung Institute of Technology, Bandung, Indonesia; \\ aliyazahra28 @ gmail.com (A.A.Z.); rika@fa.itb.ac.id (R.H.); irdafidrianny@ gmail.com (I.F.); \\ * Correspondence: aliyazahra28@gmail.com;
}

Received: 29.09.2020; Revised: 19.10.2020; Accepted: 22.10.2020; Published: 25.10.2020

\begin{abstract}
Cymbopogon is a genus of aromatic plants that famed because of the essential oil production that has many benefit in industrial, daily life, or even for disease treatment. The Cymbopogon genus consists of about 180 plants, including different species, subspecies, varieties, and subvarieties. The aim of this review is to present chemical properties, pharmacological, and development of the Cymbopogon genus from books and research studies. There were many types of research that have been done to prove the benefits of the Cymbopogon genus, including studies about the extract, essential oil, the chemical compound biological activity, and development studies. Some pharmacological studies that have been confirmed are regarding the pharmacological effects of Cymbopogon in the central nervous system, anti-inflammatory, antimicrobial, antioxidant, and anticancer activity. In addition, there have been studied to improve Cymbopogon benefits.
\end{abstract}

Keywords: Cymbopogon sp.; essential oil; biological activity; chemical properties.

(C) 2020 by the authors. This article is an open-access article distributed under the terms and conditions of the Creative Commons Attribution (CC BY) license (https://creativecommons.org/licenses/by/4.0/).

\section{Introduction}

Aromatic plants are included in the category of medicinal plants because these plants are widely used as medicine and are used to help maintain health [1]. Gramineae family is a monocot plant which is widely known as a source of essential oils that are widely used both in industry or for daily life [2]. Essential oil is a compound that can be obtained from aromatic plants and has many benefits. In this time, the use of alternative and complementary therapies has been widely developed. Aromatherapy is one of the therapies that use essential oil and has many pharmacological effects. Furthermore, in several countries, Cymbopogon sp. is used to treat indigestion, depression, headache, respiratory problems, skin problems, malaria, stomach problem, antihypertension even as a self-treatment for weight loss [3-6]. Cymbopogon sp. is also used in daily life as a flavoring agent, antiseptic and deodorant, body cleansing (drink and bath) after menstruation, enemas, and pimples, even for dental hygiene in some countries [79].

The Cymbopogon genus from the Graminae family consists of about 180, including different species, subspecies, varieties, and subvarieties. Cymbopogon plants are tall perennial plants with dense and long leaves. Some of the most important aromatic Cymbopogon species in producing essential oils are Cymbopogon martinii, Cymbopogon citratus, Cymbopogon flexuosus, Cymbopogon westratus, Cymbopogon nardus, and Cymbopogon winterianus [2].

Currently, there are many scientific publications that observe regarding pharmacological and composition of Cymbopogon genus plants. Hence this systematic review 
intends to discuss and analyze the latest research related to the Cymbopogon genus as a valuable plant that has many benefits.

\section{Materials and Methods}

This review was performed by analyzing sources from books and articles published in 2016 until 2020 that contain biological activity and chemical properties of Cymbopogon that are indexed by Scopus. The articles choosing based on: (1) article shows the chemical properties of Cymbopogon sp., (2) article that reported the biological testing activity of essential oil, extract, fraction, or pure compound of Cymbopogon sp. using in vitro or in vivo methods, (3) article that reported development studies using Cymbopogon sp. Journals published outside of 2016 to 2020 and journals that were not indexed by Scopus were excluded.

\section{Results and Discussion}

\subsection{Chemical properties.}

Studies by Gupta et al.[10], using GC and GC/MS showed that from 17 different Cymbopogon species, there were many variations in essential oils production $(0.4 \%-1.4 \%)$ and significant chemical diversification; most of them consist of neral, geranial, citronellal, and geraniol as the four main components. But plants produce a variety of structurally and functionally different metabolites that can affect the growth and development of these plants. This is influenced by environmental conditions as abiotic and biotic pressures resulting in the chemical properties/active ingredients of the same species of different plants in different diversity zones due to changes in the micro and macro environment of these plants $[1,11]$. Such as the increase of abiotic stress can increases metabolic production and the quality of essential oils in aromatic plants [12]. Major components of some essential oil of Cymbopogon sp. were summarized in Table 1.

There are many factors that can affect the results of essential oils. A previous study demonstrated that the yield of essential oil extracted from different parts of Cymbopogon winterianus produces different results, with the leaf parts having the highest yields more than the stem or the whole aerial parts. Moisture content also has been proved a significant effect on oil yield because higher essential oil content was obtained from fresh plants compared to dried plants [21]. The choice of the extracting method also can affect the results of essential oil. C. nardus essential oil that was extracted by ohmic-assisted hydrodistillation (OAHD) and hydrodistillation (HD) yielded the same amount of essential oil with similar physical properties but had different activity due to different compound value in the essential oil [22].

\subsection{Antimicrobial activity.}

Multi-Drug Resistance (MDR) bacteria is a global problem in the world of health, making the development of plant-based antimicrobials is widely studied. The constituents with or without combination with antibiotics can be effective because bacteria, fungi, and viruses may decrease their adapting ability by disturbing processes in the pathogenic process [23].

Table 1. Chemical compounds reported in Cymbopogon sp essential oil.

\begin{tabular}{l|l|l|l|l} 
Compound & Species & Percentage $\mathbf{( \% )}$ & Source & Ref \\
\hline Elemol & C. winterianus & $10.05-15.58$ & India & {$[13]$} \\
\hline Geranial /citral A & C. citratus & 48.18 & France & {$[14]$} \\
\cline { 2 - 5 } & C. citratus & 42.67 & Brazil & {$[17]$} \\
\multirow{2}{*}{ ps://biointerfaceresearch.com/ } & & & & $\mathbf{1 0 3 4 2}$
\end{tabular}




\begin{tabular}{|c|c|c|c|c|}
\hline Compound & Species & Percentage $(\%)$ & Source & Ref \\
\hline & C. citratus & 53.20 & Brazil & [16] \\
\hline \multirow[t]{3}{*}{ Neral/ citral B } & C. citratus & 34.37 & France & [14] \\
\hline & C. citratus & 33.03 & Brazil & [17] \\
\hline & C. citratus & 36.37 & Brazil & [16] \\
\hline \multirow[t]{2}{*}{ Myrecene } & C. citratus & 5.37 & France & [14] \\
\hline & C. citratus & 10.68 & Brazil & [17] \\
\hline \multirow{3}{*}{ Geraniol } & C. citratus & 4.99 & Brazil & [17] \\
\hline & C. citratus & 2.66 & Brazil & [16] \\
\hline & C. martinii & 70.26 & Brazil & [18] \\
\hline \multirow[t]{4}{*}{ Linalool } & C. martinii & 1.16 & India & [19] \\
\hline & C. martinii & 9.59 & India & [15] \\
\hline & C. martinii & 1.77 & Brazil & [18] \\
\hline & C. winterianus & $16.95-25.81$ & India & [13] \\
\hline \multirow{2}{*}{ Limonene } & C. giganteus & 19.3 & France & [14] \\
\hline & C. nardus & 3.5 & Brazil & [20] \\
\hline Mentha-1(7),8-dien-2-ol cis & C. giganteus & 17.34 & France & {$[14]$} \\
\hline $\begin{array}{l}\text { Mentha-1(7),8-dien-2-ol } \\
\text { trans }\end{array}$ & C. giganteus & 13.95 & France & [14] \\
\hline $\begin{array}{l}\text { Trans-Mentha-2,8-diene- } \\
\text { para-ol } 1\end{array}$ & C. giganteus & 13.91 & France & {$[14]$} \\
\hline $\begin{array}{l}\text { Mentha-2,8-diene-1-ol, cis- } \\
\text { para }\end{array}$ & C. giganteus & 8.1 & France & {$[14]$} \\
\hline Trans-geraniol & C. martinii & 66.9 & India & [19] \\
\hline \multirow[t]{3}{*}{ Geranyl acetate } & C. martinii & 7.5 & India & [19] \\
\hline & C. martinii & 26.71 & Brazil & [18] \\
\hline & C. citratus & 1.5 & Brazil & [16] \\
\hline$(\mathbf{E}, \mathbf{Z})$-farnesol & C. martinii & 9.43 & India & [19] \\
\hline$\beta$-ocimene & C. martinii & 0.66 & India & [19] \\
\hline \multirow[t]{2}{*}{$\beta$-caryophyllene } & C. martinii & 1.36 & India & [19] \\
\hline & C. citratus & 3.91 & Brazil & [16] \\
\hline Trans-nerolidol & C. martinii & 1.38 & India & [19] \\
\hline Caryophyllene oxide & C. martinii & 0.97 & India & [19] \\
\hline Geraniol hexanoate & C. martinii & 8.0 & India & [19] \\
\hline Fernesol acetate & C. martinii & 0.68 & India & [19] \\
\hline Geranyl octanoate & C. martinii & 1.94 & India & [19] \\
\hline Geranyl proprionate & C. martinii & 6.40 & India & [15] \\
\hline \multirow[t]{3}{*}{ Citronellal } & C. nardus & 27.52 & Brazil & [20] \\
\hline & C. winterianus & $16.33-26.83$ & India & [13] \\
\hline & C. martinii & 2.37 & India & [15] \\
\hline \multirow[t]{2}{*}{ Citronellol } & C. nardus & 25 & Brazil & [20] \\
\hline & C. winterianus & $14.26-16.30$ & India & [13] \\
\hline Nerol & C. nardus & 21.89 & Brazil & [20] \\
\hline Citronellyl acetat & C. nardus & 5.75 & Brazil & [20] \\
\hline \multirow[t]{2}{*}{ Geranyl acetate } & C. nardus & 4.53 & Brazil & [20] \\
\hline & C. martinii & 14.88 & India & [15] \\
\hline Terpinen-4-ol & C. martinii & 11.52 & India & [15] \\
\hline$\alpha$-Terpineol & C. martinii & 7.19 & India & [15] \\
\hline Thymol & C. martinii & 6.19 & India & [15] \\
\hline Germacrene D & C. nardus & 3.14 & Brazil & [20] \\
\hline
\end{tabular}

The $C$. citratus essential oil has been reported had high antimicrobial activity against gram-positive bacteria such as methicillin-resistant Staphylococcus aureus (MRSA) and methicillin-resistant Staphylococcus epidermidis (MRSE), but not significant for most of the Gram-negative bacteria [24]. Citral, one of the major compounds in C.citratus essential oil, regulated the proteins involved in transcriptional repression/activation, adhesion, and toxin activity of MRSA [25]. Citral also exposed antimicrobial activity by altering the membrane permeability of Vibrio alginolyticus, a Gram-negative marine bacterium [26]. Besides the effect on bacteria, $C$. citratus oil showed an antifungal effect against all Candida tropicalis strains with minimum inhibitory concentration (MIC) within the range $2.0-3.9 \mu \mathrm{l} / \mathrm{ml}$ by inhibiting biofilm [27]. C. citratus essential oil also had an effect of inhibiting Candida albicans, Candida krusei, Candida glabrata, Candida parapsilos, and Candida famata (MIC 
125 to $175 \mu \mathrm{g} / \mathrm{ml}$ ) [28]. In another study C.citratus essential oils gave $100 \%$ inhibition of Raffaelea quercus-mongolicae and Rhizoctonia solani (MIC 125 to $175 \mu \mathrm{g} / \mathrm{ml}$ ) in reducing the count of mold, yeast and ethanol content of the silage [29,30]

The other research stated that the essential oil of $C$. nardus (concentrations of 5x and 10x minimum bactericidal concentration) reduced biofilm of Candida albicans and Staphylococcus aureus compared to the control group that using mouthwashes [20]. An essential oil from $C$. nardus also has a significant inhibitory effect on Aspergillus niger, Aspergillus oryzae, and Aspergillus ochraceus (MIC 1-2 mg/ml) [31].

A previous study expressed that the antimicrobial effect of Cymbopogon winterianus Jowitt ex Bor. and Cymbopogon flexuosus W. Watson essential oil against Staphylococcus aureus, Micrococcus luteus, Bacillus subtilis, Escherichia coli, and Klebsiella pneumoniae. MIC of C. flexuosus essential oil within the range of $800-1000 \mu \mathrm{g} / \mathrm{ml}$ and the essential oil $C$. winterianus with MIC values lying between 1000-1500 $\mu \mathrm{g} / \mathrm{ml}$ [32].

The essential oil of C.martinii had many mechanisms for the antifungal activity such as inhibited germination of Penicillium expansum (MIC 0.125 or $0.25 \mathrm{~g} / \mathrm{l}$ ), inhibited the growth and production of ochratoxin A (OTA) of Aspergillus ochraceus( MIC $1308 \pm 16.69 \mu \mathrm{g} / \mathrm{ml}$ ) and Penicillium verrucosum (MIC $964 \pm 18.72 \mu \mathrm{g} / \mathrm{ml}$ ) [15,33]. C.martinii essential oil also inhibited toxigenic fungi of Aspergillus flavus and Aspergillus carbonarius (MIC 3.33 and $1.67 \mu \mathrm{l} / \mathrm{ml})[34]$.

\subsection{Antioxidant activity.}

It has been shown in many studies that essential oil from the Cymbopogon genus had antioxidant activity. Some of the antioxidant activity caused by phenol that known as one of the most famous compounds that have antioxidant activity, but some of them also had antioxidant activity caused by the presence of non-phenolic terpenoid. Several studies have investigated the antioxidant activity of C.citratus and C. giganteus essential oil. Citral, as a major compound of C.citratus essential oil, was statistically equal to the essential oil itself [14]. In addition, citral can reduce oxidative stress, and pro-inflammatory cytokines thus give a protective effect against UV-B -induced carcinogenesis in hairless mice [35]. Another study proved that linalool $\alpha$-monoterpene that can be found in $C$. citratus can reduce oxidative stress and mitochondrial dysfunction mediated by glutamate and NMDA toxicity [36].

Research by Kusmardiyani et al. [37] used n-hexane, ethyl acetate, and ethanol extracts that prepared using different polarity solvents methods by reflux using herbs of three kinds of lemongrass, which were $C$. citratus, $C$. martini and $C$. winterianus. The samples used to determine antioxidant activity using 2,2-diphenyl-1-picrylhydrazyl (DPPH) and ferric reducing antioxidant power (FRAP) and correlation of total phenolic content (TPC), total flavonoid content (TFC), and total carotenoid contents (TCC) with their inhibitory concentration 50\% ( $\left.\mathrm{IC}_{50}\right)$ of DPPH and exhibitory concentration 50\% (EC50) of FRAP. All samples from three kinds of lemongrass were categorized as a very strong antioxidant by DPPH method with phenolic compounds in $C$. citratus were the major contributor in antioxidant activities by DPPH and FRAP methods; meanwhile, flavonoid compounds were the major contributor in antioxidant activity of $C$. martinii by DPPH assay. 


\subsection{Antiinflamation activity.}

The other research presented some anti-inflammation effects of Cymbopogon essential oils such as $C$. citratus and $C$. giganteus by inhibiting lipoxygenase enzyme that can induce inflammation [14]. Another study revealed that geraniol, one of the monoterpenes in Cymbopogon essential oil, can inhibit Kv1.3 ion channel (voltage-gated potassium channel) with $\mathrm{IC}_{50} 0.5 \mathrm{mM}$. Kv1.3 channel expression is known as an important factor in autoimmune and chronic inflammatory diseases [38].

\subsection{Hepatoprotective activity.}

C. citratus essential oil significantly reduced 3A and Cytochrome P450 Family 1 Subfamily A Member 1 (CYP1A1) activities and lowered oxidative stress in the liver of rats. Citral as a major component of $C$. citratus essential oil may be the reason for the lowering activity of Cytochrome P450 (CYP) enzyme and oxidative stress in the rats liver [39].

\subsection{Insecticide activity.}

C. citratus essential oil (at $1 \%, 1.5 \%$, and $2 \%$ concentrations with $100 \%$ mortality) and C. nardus essential oil (at $2 \%$ concentration with $66 \%$ mortality) gave acaricidal activity against Rhipicephalus microplus larvae, which is a common pest that transmits hemiparasites [40]. C. citratus essential oil also proved insecticidal activity against Ulomoides dermestoides [41]. In addition $C$. citratus essential oil exhibited insecticidal effect against Phthorimaea operculella, a pest that damages crops such as potatoes, tobacco and tomatoes both stored and field [42].

In another study, $C$. flexuous essential oil significantly affected enzymes that help the organisms to transform or/and eliminate endogenous and exogenous compounds such as acetylcholinesterase (AChE), nonspecific esterases ( $\alpha$-and $\beta$-), glutathione S-transferases (GST), and mixed-function oxidases (MFO) in wild Aedes aegypti [43].

The other research used essential oil as a repellent against home flies (Musca domestica). Tablet combination of essential oil from $C$. citratus and $C$. nardus with essential oil from the clove was the most effective [44].

\subsection{Antiparasite activity.}

C. citratus essential oil showed trypanocidal activity on parasite Trypanosoma brucei using bloodstream trypomastigotes cultures of $T$. $b$. brucei and also had anthelmintic activity against parasitic plathelminths (monogeneans) in Colossoma macropomum (Serrasalmidae) $[45,46]$.

\subsection{Anticancer activity.}

C. citratus and C. giganteus essential oils inhibited the cell growth of human prostate cancer cell lines (LNCaP and PC-3) and human glioblastoma cell lines (SF-767 and SF-763) [14]. The essential oil of $C$. flexuosus reduced the expression of the HSP90 gene significantly in MCF-7 (breast cancer cell lines) compared to HEK-293 [47]. 


\subsection{Antiglycation activity.}

Diabetes mellitus has been known to be linked to oxidative stress and nonenzymatic protein glycation. The essential oil of $C$. schoenanthus has moderate glycation inhibitors when compared to aminoguanidine as control [48].

\subsection{Influence on the nervous system.}

Major compounds of Cymbopogon essential oil such as S-(+)-linalool, one of the major compounds of $C$. nardus showed sedative and anesthetic effects in silver catfish (Rhamdia quelen) [49]. Citral also can induce analgesia in arthritic rats by modulating spinal nociceptive signaling [50]. Citronellal and linalool also provided anesthetic efficacy in common carp (Cyprinus carpio) by inducing deep anesthesia [51].

Anxiolytics are used to prevent and treat symptoms of anxiety disorders. The essential oil of C.citratus at a concentration of $10 \mathrm{mg} / \mathrm{l}$ caused significant anxiolysis in zebrafish by increasing the time spent in the light compartment of the tank [52]. Not only the essential oil, but aqueous leaf extract of $C$. citratus also effected neurobehavioral. In vivo study with male mice induced by SDS confirmed the effect of $C$. citratus aqueous extracts such as decreasing heightened anxiety, hyperlocomotion, depressive-like symptom, memory deficit, and social avoidance. These studies proved that C.citratus aqueous extract modulated modified levels of oxidative stress and acetyl-cholinesterase in SDS-mice [53]. Another study figured the effect of $C$. citratus as neuroprotective. Rats that were treated by $\mathrm{AlCl}_{3}(17 \mathrm{mg} / \mathrm{kg} /$ day $)$ showed elevated levels of A $\beta$ peptides, tau proteins, MDA, NF-kB, and IL- 6 and altered brain tissues to induce Alzheimer's condition. The rats that treated with $\mathrm{AlCl}_{3}$ along with aqueous extract (obtained by infusion) and ethanolic extract (obtained by maceration in $90 \%$ ethanol) of C.citratus has $a$ significant reduction in the hippocampal contents of A $\beta$ peptides and tau protein after administration doses of 250 and $500 \mathrm{mg} / \mathrm{kg}$ for aqueous extract or $125 \mathrm{mg} / \mathrm{kg}$ for ethanolic extract [54].

Ethanol extract of $C$. schoenanthus that was obtained by macerated dried-air leaves of C. schoenanthus in $70 \%$ ethanol for 2 weeks had anti-stress potential. Ethanol extract of $C$. schoenanthus had an activity to increase the recovery acetylcholine (Ach) compared to heatstressed SH-SY5Y cells; thus, this extract can be a new source to treat stress-related diseases [55].

A putative mechanism that could support in treating diarrhea has been studied to butanol and ethanol extracts of $C$. schoenanthus that prepared by liquid-liquid extractions tested on the distal rat colon, on the basal tone, and on $\mathrm{KCl}$ - and Ach-induced precontracted preparations. The result exposed that ethyl acetate extract reverted both the $\mathrm{KCl}$ - and the Achinduced precontraction of the distal rat colon, but n-butanol extract just affected the Achprecontracted colon probably because there was a distinction in their extract component [56].

\subsection{Cymbopogon sp. and nanoparticles.}

Nanoparticles are a well-studied delivery system, some of which exist to reducing toxicity, sustained and controlled release, deliver drugs with poor solubility or increase therapeutic targets [57]. Cymbopogon genus that has many benefits is one of the targets of development with nanoparticles. Studies by Jummes et al. [18] improved the essential oil from C. martinii with the help of poly-e-caprolactone nanoparticles to support and increased the 
stability of essential oils. With this nanoprecipitation method, the combination of encapsulated with good stability is proven by the zeta potential and polydispersity index. Encapsulation also has proven to significantly reduce the cytotoxicity of $C$. citratus essential oils tested with human HaCat keratinocytes by WST-1 and LDH assays when encapsulated with PLGA nanoparticle [17]. The use of nanoparticles also helped in the formulation to increase pharmacological effects. $C$. citratus essential oil has been successfully encapsulated with poly nanoparticles (D, L-lactide-co-glycolida) made into hydrogels. This formula prevents the Herpes simplex virus in non-cytotoxic concentrations, 42.16 times lower than free oils without encapsulation, 8.76, and 2.23 times that of nanoparticles and hydrogels that are containing free essential oils [16].

\section{Conclusions}

This review proved that plants of the genus Cymbopogon are very interesting because Cymbopogon in the extract form or essential oil form has a lot of compounds with plentiful biological activities that are useful for the development of drugs from natural ingredients. Lots of research have been done to prove the benefits of Cymbopogon citratus essential oil as one of the commodities that produce essential oils from the Cymbopogon and citral as one of the main components of their essential oils, but there is also a study about the extracts and other Cymbopogon species. Some pharmacological studies that have been confirmed are regarding the pharmacological effects of Cymbopogon in the central nervous system, anti-inflammatory, antimicrobial, antioxidant, and anticancer. In addition, there have been many studies using nanoparticles to improve the deficiency of Cymbopogon essential oil to enhance its pharmacological effects.

\section{Funding}

This research received no external funding.

\section{Acknowledgments}

The authors wish to respect the facilities support of the Department of Pharmaceutical Biology, School of Pharmacy, Bandung Institute of Technology, Indonesia.

\section{Conflicts of Interest}

No conflict of interest was declared by the authors. The authors alone are responsible for the content and writing of this article.

\section{References}

1. Pandey, A.K.; Kumar, P.; Saxena, M.J.; Maurya, P. Chapter 6 - Distribution of aromatic plants in the world and their properties. In: Feed Additives. Florou-Paneri, P.; Christaki, E.; Giannenas, I.B.T.-F.A. Eds.; Academic Press, 2020; pp. 89-114, https://doi.org/10.1016/B978-0-12-814700-9.00006-6.

2. Bertea, C.M.; Maffei, M.E. Essential oil bearing grasses the genus Cymbopogon. CRC Press : Boca Raton, United States , 2009; pp 1-4, https://doi.org/10.1201/9780849378584.

3. Ali, B.; Al-Wabel, N.A.; Shams, S.; Ahamad, A.; Khan, S.A.; Anwar, F. Essential oils used in aromatherapy: A systemic review. Asian Pac J Trop Biomed 2015, 5, 601-611, https://doi.org/10.1016/j.apjtb.2015.05.007.

4. Oyeyemi, I.T.; Akinseye, K.M.; Adebayo, S.S.; Oyetunji, M.T.; Oyeyemi, O.T. Ethnobotanical survey of the plants used for the management of malaria in Ondo State, Nigeria. South African J Bot 2019, 124, 391401, https://doi.org/10.1016/j.sajb.2019.06.003. 
5. Caballero-Serrano, V.; McLaren, B.; Carrasco, J.C.; Alday, J.G.; Fiallos, L.; Amigo, J.; Onaindia, M. Traditional ecological knowledge and medicinal plant diversity in Ecuadorian Amazon home gardens. Glob Ecol Conserv 2019, 17, https://doi.org/10.1016/j.gecco.2019.e00524.

6. Alonso-Castro, A.J.; Ruiz-Padilla, A.J.; Ramírez-Morales, M.A.; Alcocer-García, S.G.; Ruiz-Noa, Y.; Ibarra-Reynoso, L.D.R.; Solorio-Alvarado, C.R.; Zapata-Morales, J.R.; Mendoza-Macías, C.L.; DevezeÁlvarez, M.A.; Alba-Betancourt, C. Self-treatment with herbal products for weight-loss among overweight and obese subjects from central Mexico. J Ethnopharmacol 2019, 234, 21-26, https://doi.org/10.1016/j.jep.2019.01.003.

7. Fongnzossie, E.F.; Tize, Z.; Fogang Nde, P.J.; Nyangono Biyegue, C.F.; Bouelet Ntsama, I.S.; Dibong, S.D.; Nkongmeneck, B.A. Ethnobotany and pharmacognostic perspective of plant species used as traditional cosmetics and cosmeceuticals among the Gbaya ethnic group in Eastern Cameroon. South African J Bot 2017, 112, 29-39, https://doi.org/10.1016/j.sajb.2017.05.013.

8. Gishen, N.Z.; Taddese, S.; Zenebe, T.; Dires, K.; Tedla, A.; Mengiste, B.; Shenkute, D.; Tesema, A.; Shiferaw, Y.; Lulekal, E. In vitro antimicrobial activity of six Ethiopian medicinal plants against Staphylococcus aureus, Escherichia coli and Candida albicans. Eur J Integr Med 2020, 36, https://doi.org/10.1016/j.eujim.2020.101121.

9. Gebashe, F.; Moyo, M.; Aremu, A.O.; Finnie, J.F.; Van Staden, J. Ethnobotanical survey and antibacterial screening of medicinal grasses in KwaZulu-Natal Province, South Africa. South African J Bot 2019, 122, 467-474, https://doi.org/10.1016/j.sajb.2018.07.027.

10. Gupta, P.; Mishra, A.; Yadav, A.; Dhawan, S.S. Inter and intra-specific molecular and chemical diversity of elite accessions of aromatic grasses Cymbopogons. J Appl Res Med Aromat Plants 2018, 11, 54-60, https://doi.org/10.1016/j.jarmap.2018.10.005.

11. Wang, S.; Alseekh, S.; Fernie, A.R.; Luo, J. The Structure and function of major plant metabolite modifications. Mol Plant 2019, 12, 899-919, https://doi.org/10.1016/j.molp.2019.06.001.

12. Mahajan, M.; Kuiry, R.; Pal, P.K. Understanding the consequence of environmental stress for accumulation of secondary metabolites in medicinal and aromatic plants. J Appl Res Med Aromat Plants 2020, 18, https://doi.org/10.1016/j.jarmap.2020.100255.

13. Solanki, K.P.; Desai, M.A.; Parikh, J.K. Microwave intensified extraction: A holistic approach for extraction of citronella oil and phenolic compounds. Chem Eng Process - Process Intensif 2019, 146, https://doi.org/10.1016/j.cep.2019.107694.

14. Bayala, B.; Bassole, I.H.N.; Maqdasy, S.; Baron, S.; Simpore, J.; Lobaccaro, J.-M.A. Cymbopogon citratus and Cymbopogon giganteus essential oils have cytotoxic effects on tumor cell cultures. Identification of citral as a new putative anti-proliferative molecule. Biochimie 2018, 153, 162-170, https://doi.org/10.1016/j.biochi.2018.02.013.

15. Kalagatur, N.K.; Gurunathan, S.; Kamasani, J.R.; Gunti, L.; Kadirvelu, K.; Mohan, C.D.; Rangappa, S.; Prasad, R.; Almeida, F.; Mudili, V.; Siddaiah, C. Inhibitory effect of C. zeylanicum, C. longa, O. basilicum, Z. officinale, and C. martini essential oils on growth and ochratoxin A content of A. ochraceous and $P$. verrucosum in maize grains. Biotechnol Reports 2020, 27, https://doi.org/10.1016/j.btre.2020.e00490.

16. Almeida, K.B.; Araujo, J.L.; Cavalcanti, J.F.; Romanos, M.T. V; Mourão, S.C.; Amaral, A.C.F.; Falcão, D.Q. In vitro release and anti-herpetic activity of Cymbopogon citratus volatile oil-loaded nanogel. Rev Bras Farmacogn 2018, 28, 495-502, https://doi.org/10.1016/j.bjp.2018.05.007.

17. Almeida, K.B.; Ramos, A.S.; Nunes, J.B.B.; Silva, B.O.; Ferraz, E.R.A.; Fernandes, A.S.; Felzenszwalb, I.; Amaral, A.C.F.; Roullin, V.G.; Falcão, D.Q. PLGA nanoparticles optimized by Box-Behnken for efficient encapsulation of therapeutic Cymbopogon citratus essential oil. Colloids Surf B Biointerfaces 2019, 181, 935-942, https://doi.org/10.1016/j.colsurfb.2019.06.010.

18. Jummes, B.; Sganzerla, W.G.; da Rosa, C.G.; Noronha, C.M.; Nunes, M.R.; Bertoldi, F.C.; Barreto, P.L.M. Antioxidant and antimicrobial poly- $\varepsilon$-caprolactone nanoparticles loaded with Cymbopogon martinii essential oil. Biocatal Agric Biotechnol 2020, 23, https://doi.org/10.1016/j.bcab.2020.101499.

19. Kaur, G.; Arya, S.K.; Singh, B.; Singh, S.; Dhar, Y.V.; Verma, P.C.; Ganjewala, D. Transcriptome analysis of the palmarosa Cymbopogon martinii inflorescence with emphasis on genes involved in essential oil biosynthesis. Ind Crops Prod 2019, 140, https://doi.org/10.1016/j.indcrop.2019.111602.

20. Guandalini Cunha, B.; Duque, C.; Sampaio Caiaffa, K.; Massunari, L.; Araguê Catanoze, I.; dos Santos, D.M.; de Oliveira, S.H.P.; Guiotti, A.M. Cytotoxicity and antimicrobial effects of citronella oil (Cymbopogon nardus) and commercial mouthwashes on $S$. aureus and C. albicans biofilms in prosthetic materials. Arch Oral Biol 2020, 109, https://doi.org/10.1016/j.archoralbio.2019.104577.

21. Timung, R.; Barik, C.R.; Purohit, S.; Goud, V.V. Composition and anti-bacterial activity analysis of citronella oil obtained by hydrodistillation: Process optimization study. Ind Crops Prod 2016, 94, 178-188, https://doi.org/10.1016/j.indcrop.2016.08.021.

22. Gavahian, M.; Lee, Y.-T.; Chu, Y.-H. Ohmic-assisted hydrodistillation of citronella oil from Taiwanese citronella grass: Impacts on the essential oil and extraction medium. Innov Food Sci Emerg Technol 2018, 48, 33-41, https://doi.org/10.1016/j.ifset.2018.05.015.

23. Gupta, P.D.; Birdi, T.J. Development of botanicals to combat antibiotic resistance. J Ayurveda Integr Med 2017, 8, 266-275, https://doi.org/10.1016/j.jaim.2017.05.004. 
24. Subramaniam, G.; Yew, X.Y.; Sivasamugham, L.A. Antibacterial activity of Cymbopogon citratus against clinically important bacteria. South African J Chem Eng 2020, 34, 26-30, https://doi.org/10.1016/j.sajce.2020.05.010.

25. Valliammai, A.; Sethupathy, S.; Ananthi, S.; Priya, A.; Selvaraj, A.; Nivetha, V.; Aravindraja, C.; Mahalingam, S.; Pandian, S.K. Proteomic profiling unveils citral modulating expression of IsaA, CodY and SaeS to inhibit biofilm and virulence in Methicillin-resistant Staphylococcus aureus. Int J Biol Macromol 2020, 158, 208-221, https://doi.org/10.1016/j.ijbiomac.2020.04.231.

26. Liu, H.; Wang, Y.; Cao, J.; Jiang, H.; Yao, J.; Gong, G.; Chen, X.; Xu, W.; He, X. Antimicrobial activity and virulence attenuation of citral against the fish pathogen Vibrio alginolyticus. Aquaculture 2020, 515 , https://doi.org/10.1016/j.aquaculture.2019.734578.

27. Sahal, G.; Woerdenbag, H.J.; Hinrichs, W.L.J.; Visser, A.; Tepper, P.G.; Quax, W.J.; van der Mei, H.C.; Bilkay, I.S. Antifungal and biofilm inhibitory effect of Cymbopogon citratus (lemongrass) essential oil on biofilm forming by Candida tropicalis isolates; an in vitro study. J Ethnopharmacol 2020, 246, https://doi.org/10.1016/j.jep.2019.112188.

28. Khosravi, A.R.; Sharifzadeh, A.; Nikaein, D.; Almaie, Z.; Gandomi Nasrabadi, H. Chemical composition, antioxidant activity and antifungal effects of five Iranian essential oils against Candida strains isolated from urine samples. J Mycol Med 2018, 28, 355-360, https://doi.org/10.1016/j.mycmed.2018.01.005.

29. Lee, J.-E.; Seo, S.-M.; Huh, M.-J.; Lee, S.-C.; Park, I.-K. Reactive oxygen species mediated-antifungal activity of cinnamon bark (Cinnamomum verum) and lemongrass (Cymbopogon citratus) essential oils and their constituents against two phytopathogenic fungi. Pestic Biochem Physiol 2020, 168, https://doi.org/10.1016/j.pestbp.2020.104644.

30. Cantoia Júnior, R.; Capucho, E.; Garcia, T.M.; Del Valle, T.A.; Campana, M.; Zilio, E.M.C.; Azevedo, E.B.; Morais, J.P.G. Lemongrass essential oil in sugarcane silage: Fermentative profile, losses, chemical composition, and aerobic stability. Anim Feed Sci Technol 2020, 260, https://doi.org/10.1016/j.anifeedsci.2019.114371.

31. Hu, F.; Tu, X.-F.; Thakur, K.; Hu, F.; Li, X.-L.; Zhang, Y.-S.; Zhang, J.-G.; Wei, Z.-J. Comparison of antifungal activity of essential oils from different plants against three fungi. Food Chem Toxicol 2019, 134, https://doi.org/10.1016/j.fct.2019.110821.

32. Sharma, K.; Guleria, S.; Razdan, V.K.; Babu, V. Synergistic antioxidant and antimicrobial activities of essential oils of some selected medicinal plants in combination and with synthetic compounds. Ind Crops Prod 2020, 154, https://doi.org/10.1016/j.indcrop.2020.112569.

33. Cezar, A.; Bachiega, B.; Canton, L.; Maraschin, M.; Marcelo, R.; Piero, D. Antifungal activity of palmarosa (Cymbopogon martinii), tea tree (Melaleuca alternifolia) and star anise (Illicium verum) essential oils against Penicillium expansum and their mechanisms of action. LWT - Food Sci Technol 2019, 105, 385-392, https://doi.org/10.1016/j.lwt.2019.02.060.

34. Wang, H.; Yang, Z.; Ying, G.; Yang, M.; Nian, Y.; Wei, F.; Kong, W. Antifungal evaluation of plant essential oils and their major components against toxigenic fungi. Ind Crops Prod 2018, 120, 180-186, https://doi.org/10.1016/j.indcrop.2018.04.053.

35. Kremer, J.L.; Melo, G.P.; Marinello, P.C.; Bordini, H.P.; Rossaneis, A.C.; Sábio, L.R.; Cecchini, R.; Cecchini, A.L.; Verri, W.A.; Luiz, R.C. Citral prevents UVB-induced skin carcinogenesis in hairless mice. J Photochem Photobiol B Biol 2019, 198, https://doi.org/10.1016/j.jphotobiol.2019.111565.

36. Sabogal-Guáqueta, A.M.; Hobbie, F.; Keerthi, A.; Oun, A.; Kortholt, A.; Boddeke, E.; Dolga, A. Linalool attenuates oxidative stress and mitochondrial dysfunction mediated by glutamate and NMDA toxicity. Biomed Pharmacother 2019, 118, https://doi.org/10.1016/j.biopha.2019.109295.

37. Kusmardiyani, S.; Alfianti, F.; Fidrianny, I. Antioxidant profile and phytochemical content of three kinds of lemon grass grown in West Java-Indonesia. Asian J Pharm Clin Res 2016, 9.

38. Ye, C.-J.; Li, S.-A.; Zhang, Y.; Lee, W.-H. Geraniol targets KV1.3 ion channel and exhibits antiinflammatory activity in vitro and in vivo. Fitoterapia 2019, 139, https://doi.org/10.1016/j.fitote.2019.104394.

39. Li, C.-C.; Yu, H.-F.; Chang, C.-H.; Liu, Y.-T.; Yao, H.-T. Effects of lemongrass oil and citral on hepatic drug-metabolizing enzymes, oxidative stress, and acetaminophen toxicity in rats. J Food Drug Anal 2018, 26, 432-438, https://doi.org/10.1016/j.jfda.2017.01.008.

40. da Silva, L.C.; de Souza Perinotto, W.M.; Sá, F.A.; de Souza, M.A.A.; de Oliveira Barbosa Bitencourt, R.; Sanavria, A.; Santos, H.A.; Marie-Magdeleine, C.; da Costa Angelo, I. In vitro acaricidal activity of Cymbopogon citratus, Cymbopogon nardus and Mentha arvensis against Rhipicephalus microplus (Acari: Ixodidae). Exp Parasitol 2020, 216, https://doi.org/10.1016/j.exppara.2020.107937.

41. Plata-Rueda, A.; Martínez, L.C.; da Silva Rolim, G.; Coelho, R.P.; Dos Santos, M.H.; de Souza Tavares, W.; Zanuncio, J.C.; Serrão, J.E. Insecticidal and repellent activities of Cymbopogon citratus (Poaceae) essential oil and its terpenoids (citral and geranyl acetate) against Ulomoides dermestoides. Crop Prot 2020, 137, https://doi.org/10.1016/j.cropro.2020.105299.

42. Jovanović, J.; Krnjajić, S.; Ćirković, J.; Radojković, A.; Popović, T.; Branković, G.; Branković, Z. Effect of encapsulated lemongrass (Cymbopogon citratus L.) essential oil against potato tuber moth Phthorimaea operculella. Crop Prot 2020, 132, https://doi.org/10.1016/j.cropro.2020.105109. 
43. Carreño Otero, A.L.; Palacio-Cortés, A.M.; Navarro-Silva, M.A.; Kouznetsov, V.V.; Duque, L.J.E. Behavior of detoxifying enzymes of Aedes aegypti exposed to girgensohnine alkaloid analog and Cymbopogon flexuosus essential oil. Comp Biochem Physiol Part - C Toxicol Pharmacol 2018, 204, 14-25, https://doi.org/10.1016/j.cbpc.2017.11.002.

44. Hazarika, H.; Tyagi, V.; Krishnatreyya, H.; Islam, J.; Boruah, D.; Kishor, S.; Chattopadhyay, P.; Zaman, K. Essential oil based controlled-release non-toxic evaporating tablet provides effective repellency against Musca domestica. Acta Trop 2020, 210, https://doi.org/10.1016/j.actatropica.2020.105620.

45. Costa, S.; Cavadas, C.; Cavaleiro, C.; Salgueiro, L.; do Céu Sousa, M. In vitro susceptibility of Trypanosoma brucei to selected essential oils and their major components. Exp Parasitol 2018, 190, 34-40, https://doi.org/10.1016/j.exppara.2018.05.002.

46. Gonzales, A.P.P.F.; Yoshioka, E.T.O.; Mathews, P.D.; Mertins, O.; Chaves, F.C.M.; Videira, M.N.; TavaresDias, M. Anthelminthic efficacy of Cymbopogon citratus essential oil (Poaceae) against monogenean parasites of Colossoma macropomum (Serrasalmidae), and blood and histopathological effects. Aquaculture 2020, 528, https://doi.org/10.1016/j.aquaculture.2020.735500.

47. Gaonkar, R.; Shiralgi, Y.; Lakkappa, D.B.; Hegde, G. Essential oil from Cymbopogon flexuosus as the potential inhibitor for HSP90. Toxicol Reports 2018, 5, 489-496, https://doi.org/10.1016/j.toxrep.2018.03.014.

48. Mahomoodally, F.; Aumeeruddy-Elalfi, Z.; Venugopala, K.N.; Hosenally, M. Antiglycation, comparative antioxidant potential, phenolic content and yield variation of essential oils from 19 exotic and endemic medicinal plants. Saudi J Biol Sci 2019, 26, 1779-1788, https://doi.org/10.1016/j.sjbs.2018.05.002.

49. Erbice Bianchini, A.; Garlet, Q.I.; Rodrigues, P.; de Freitas Souza, C.; de Lima Silva, L.; Casale dos Santos, A.; Heinzmann, B.M.; Baldisserotto, B. Pharmacokinetics of S-(+)-linalool in silver catfish (Rhamdia quelen) after immersion bath: An anesthetic for aquaculture. Aquaculture 2019, 506, 302-307, https://doi.org/10.1016/j.aquaculture.2019.03.044.

50. Mota, C.M.D.; Rodrigues-Santos, C.; Carolino, R.O.G.; Anselmo-Franci, J.A.; Branco, L.G.S. Citralinduced analgesia is associated with increased spinal serotonin, reduced spinal nociceptive signaling, and reduced systemic oxidative stress in arthritis. $J$ Ethnopharmacol 2020, 250, https://doi.org/10.1016/j.jep.2019.112486.

51. Yousefi, M.; Hoseinifar, S.H.; Ghelichpour, M.; Hoseini, S.M. Anesthetic efficacy and biochemical effects of citronellal and linalool in common carp (Cyprinus carpio Linnaeus, 1758) juveniles. Aquaculture 2018, 493, 107-112, https://doi.org/10.1016/j.aquaculture.2018.04.054.

52. Mendes Hacke, A.C.; Miyoshi, E.; Marques, J.A.; Pereira, R.P. Anxiolytic properties of Cymbopogon citratus (DC.) stapf extract, essential oil and its constituents in zebrafish (Danio rerio). J Ethnopharmacol 2020, 260, https://doi.org/10.1016/j.jep.2020.113036.

53. Umukoro, S.; Ben-Azu, B.; Ajayi, A.M.; Adebesin, A.; Emokpae, O. Cymbopogon citratus aqueous leaf extract attenuates neurobehavioral and biochemical changes induced by social defeat stress in mice. Chinese Herb Med 2020, 12, 303-309, https://doi.org/10.1016/j.chmed.2020.01.002.

54. Madi, Y.F.; Choucry, M.A.; El-Marasy, S.A.; Meselhy, M.R.; El-Kashoury, E.-S.A. UPLC-Orbitrap HRMS metabolic profiling of Cymbopogon citratus cultivated in Egypt; neuroprotective effect against $\mathrm{AlCl3}$ induced neurotoxicity in rats. J Ethnopharmacol 2020, 259, https://doi.org/10.1016/j.jep.2020.112930.

55. Ben Othman, M.; Neffati, M.; Isoda, H. Evaluation of the anti-stress effects of five Tunisian aromatic and medicinal plants in vitro. J Herb Med 2018, https://doi.org/10.1016/j.hermed.2018.10.003.

56. Djemam, N.; Lassed, S.; Gül, F.; Altun, M.; Monteiro, M.; Menezes-Pinto, D.; Benayache, S.; Benayache, F.; Zama, D.; Demirtas, I.; Morato, M. Characterization of ethyl acetate and n-butanol extracts of Cymbopogon schoenanthus and Helianthemum lippii and their effect on the smooth muscle of the rat distal colon. J Ethnopharmacol 2020, 252, https://doi.org/10.1016/j.jep.2020.112613.

57. Ghaffari, M.; Dolatabadi, J.E.N. Chapter 17 - Nanotechnology for pharmaceuticals. In: Micro and Nano Technologies. Thomas, S.; Grohens, Y.; Pottathara, Y.B.B.T.-I.A.N. Eds.; Elsevier, 2019; pp. 475-502, https://doi.org/10.1016/b978-0-12-815749-7.00017-7. 